\title{
Violent death in the lives of police officers in Ghana; An evidence-based study.
}

\author{
Awaisu I. Braimah ${ }^{1}$ and Alhassan S. Bawah ${ }^{2}$ \\ ${ }^{1}$ Department of Political Science Education, \\ University of Education, Winneba \\ P. O. Box 25, Winneba, C/R, Ghana \\ ${ }^{2}$ Department of Marketing, Procurement \& \\ Supply Chain Management, \\ University of Education, Winneba \\ P. O. Box 25, Winneba, C/R, Ghana
}

\begin{abstract}
:
This article examines the recurrent and widespread spate of civilian attacks on police personnel in Ghana. It is an undeniable fact that police actions and inactions has led to civilian injuries and deaths in Ghana. Extensive media reportage on these incidences of police militarization and brutalities has painted the police service, albeit negatively, as an institution acknowledged for inflicting pain, torture, injury and killing of civilians at the least provocation. This perception has broken down police-community relations, which is one of the core mechanisms in crime detection and prevention in modern policing. Violent attacks on police personnel by a section of the Ghanaian public leading to injuries and in some extreme cases death, appears institutionalized.

As a result, violent attacks on the police is not perceived as an issue, either because of the quietism of the police administration itself, or it could be that the media perceive these unprovoked attacks on the police, as part of the occupational hazards and/or a fitting retribution for the police. In either way, the lives of police officers matter, just as the lives of the citizens they are mandated by law to protect. This study thematically focused on the changing trend of violent deaths in the lives of police officers killed in the line of duty by civilian assailants or criminal elements within the Ghanaian society. The paper argues that violent deaths and injuries caused to police officers have not been given the needed attention due to the ongoing antagonistic relationship between the police administration and the general Ghanaian public.
\end{abstract}

Keywords: Antagonistic, Injury, Mistrust, Police administration, Recriminatory Arguments.

\section{Introduction}

Modern States across the world invest heavily in domestic security for the purposes of peace, stability and national development. Peace and stability of a State is sine qua non to any meaningful and sustainable development. The police service is mandated by law to psychologically and physically protect life and property; and to preside over general security issues of the State as part of the continuum of its core functions. Policing is effective, efficient and successful if there is greater collaboration between the police and the citizenry. Arguably, the police administration and its personnel interact with the general public more than any other State institution. They have regularly engaged citizens in the discharge of their core mandate through various means. These include receiving distress calls from individuals and organizations, crime detection and prevention, combat operations, prosecution, traffic control, patrols, crowd control, policing financial institutions to ward off potential robbers, providing security to high profile personalities, protection of key national installations, etc. It is mind-boggling and surprising that, relations between the police service and the citizenry, can at best be described as 
acrimonious. This conundrum has largely exposed both the police and the civilian populace, to violent attacks leading to unnecessary injuries and deaths on both sides, arising out of the actions of some triggerhappy police personnel, criminal bandits and societal deviance or miscreants.

Civilian injuries and deaths resulting from police use of 'reasonable or minimal force' occurs at alarming frequency in Ghana (Margarita, 1980). The extensive media coverage or publicity on these incidences has not only depicted the police in a negative limelight, but has clandestinely portrayed it as a subject of ridicule and hatred among a section of the Ghanaian public - indeed, the police-media relations in Ghana is fraught with mistrust and hatred. Many journalists have been victims of police brutalities while in the course of discharging their lawful duties. Some politicians, human rights activists, teachers, health professionals, businessmen and women, students etc., all in one way or the other, have had bitter encounters with the police in the execution of their functions. The most prominent and distinguishing feature of the police service from other security services is that the police are empowered:

...to apply coercive force when circumstances call for it. Police may be called in to use reasonable force when making an arrest, breaking up an altercation, dispersing an unruly crowd, or in the course of carrying out a myriad of other official activities. The coercive force may range from simply shouting (ordering someone to stop or move, or ordering an action to be stopped or continued) or the use of a firearm. Between these extremes, are several other types of applicable forces, such as pinning a person to the ground and holding them firmly, and proceed to lock the hands firmly behind; or the use of debilitating chemical agents such as tear gas; beating with batons; and in some instances, the delivery of bare-knuckle blows. Whatever method is used, police are expected to apply only the force necessary to resolve a given situation (McEwen, p. 1)

Most often, attempts by police officers to apply 'reasonable or minimal force', often turns bloody. Some citizens are shot dead in broad daylight either consciously or unconsciously; others are maimed during demonstrations or protests; and arbitrary arrests and detention of citizens without charge or prosecution among others. Even though the Ghana
Police Service handbook (p. 26) succinctly outlines the circumstances justifying the use of firearms by its personnel, some police officers over the years, have shown gross incompetence in the use of firearms that has resulted in civilian injuries and deaths. These incidences have created a strain relation between the police service and the wider public.

In recent times however, alleged police 'brutality' against civilians has receded. Ironically, there is an upsurge and an overwhelming increased attacks on police officers in their line of duty by a section of the public, which has unfortunately led to injuries and deaths of some police officers. These attacks and violence against the police is yet to receive the same attention or public outcry like when a citizen is injured or shot dead by the police. This is compounded by the widespread distrust between the police administration and the citizenry. The posture of the Ghanaian public towards the ever-increasing violence against some police personnel seem to suggest that, 'it serves the police right' and 'is another police officer shot dead or injured' attitude. The reaction of a section of the public to the reportage of both the electronic and print media on attacks on police personnel is shocking. The reportage is in most instances, greeted with indifference. No remorse is shown towards the affected police personnel families, relatives and colleagues of the injured or dead police officers (Bernasconi, 2014). The seemingly 'institutionalization' of violent death, crime and injury against the police, places them at high risks of both physical (e.g., beatings resulting in severe injuries, being shot to death, mob attacks on police facilities, etc) and psychological 'soft' power attacks. 'Soft power' attack is narrowly construed in this paper to mean, the interferences on the workings of the police by powerful individuals and other petit bourgeoisies in society. While the general public blame the police for the use of excessive force resulting in civilian injuries and deaths, the police in the same vein, blame civilian attacks on its personnel as one of the main causes of the strain relations.

The blame jigsaw that characterizes the relationship between the police service and its civilian counterparts, necessitated a study of this nature to be conducted with the overall aim of strengthening police-civilian relations in Ghana. This research was also to examine time variations in reported injuries and violent deaths of police officers at the hands of civilians. The study was to further sample and solicit the views and perceptions of police officers on the 
root causes of police-civilian imbroglio resulting in violent attacks and mistrust.

\section{Participants}

Data and information for this research was originally collected from March 2004 to September 2017. The researchers used purpose sampling to select 100 police officers across various police posts in Accra (the capital city of Ghana). The targeted population was the police because, they are the victims of civilian attacks in recent times. These officers were randomly selected based on their experience in police operations and knowledge regarding various civilian attacks or assaults on them (police officers) leading to injuries and death. Thus, key informants were all police officers in the capital city of Accra, between the ages of 20 and 45 years. The study was limited to the capital city because of the high concentration of reported cases of policecivilian violence. The police participants were drawn from both junior and senior police officers with experiences ranging from 5 to 20 years and above. Educationally, many of the junior ranked police officers who participated in the study holds Senior High School and Bachelor degrees (68\%) certificates. Senior police officers who participated in the research hold both Bachelors and Master's degree certificates. A total of 100 police officers completed the questionnaires $(80 \%$ males and $20 \%$ females). The low participation of police women $(20 \%)$ was due to the 'fear' of losing their jobs and victimization from superiors, in spite of the assurances of anonymity from the research team. This did not in any way affect the quality or substance of the research in a negative way.

\subsection{Instrument}

This is purely a qualitative study. Hence, the main instrument employed in the data collection for this study was questionnaire, constructed in simple language to serve the needs and understanding of both junior and senior police officers. The purpose for adopting the questionnaire was 'to give ample time to respondents to reflect adequately in order to provide appropriate and accurate answers' (Braimah et'al, 2017 p. 29). The questionnaire was structured into three main sections. The first section of the questionnaire gathered/collected the demographic or biota of participants - gender and age, rank, number of years of service in the police service, language (s) spoken, officer's department and nature of job schedule. The category of participants for this study are summarized in a tabular form for a clearer picture or explanation.
Table 1: Category of Respondents

\begin{tabular}{|l|l|l|l|}
\hline $\begin{array}{l}\text { Category } \\
\text { of } \\
\text { Responden } \\
\text { ts }\end{array}$ & $\begin{array}{l}\text { Number } \\
\text { Interview } \\
\text { ed }\end{array}$ & Rank & $\begin{array}{l}\text { Number } \\
\text { of Years } \\
\text { in } \\
\text { Service } \\
\text { (Averag } \\
\text { e) }\end{array}$ \\
\hline $\begin{array}{l}\text { Senior } \\
\text { Police } \\
\text { Officers }\end{array}$ & 19 & $\begin{array}{l}\text { Assistant } \\
\text { Superintende } \\
\text { nt of Police } \\
\text { and above }\end{array}$ & 15 \\
\hline $\begin{array}{l}\text { Junior } \\
\text { Police } \\
\text { Officers }\end{array}$ & 81 & $\begin{array}{l}\text { Constable, } \\
\text { Lance } \\
\text { Corporal, } \\
\text { Corporal, } \\
\text { Sergeants } \\
\text { and } \\
\text { Inspectors }\end{array}$ & 6 \\
\hline Total & 100 & 6 & \\
\hline
\end{tabular}

\section{Source: Field Report, 2018}

The second section measures the extent of variations in reported injuries and violent deaths of police officers. The third and final section sampled views of participants on the main causes of police-civilian strain relations. The questionnaire was structured in both multiple-choice and constructed options. The latter enabled participants to think through critically before providing justifications for their answers. The questionnaire was piloted on 20 police officers in the study area. There was some modicum of corrections on the instrument based on the nature of feedback received. The purpose of the correction was to reflect the focus of the study. The primary source of data and information was complemented by secondary data gleaned from books; journal articles; newspapers; annual statistics from the Ghana Police Service on police injuries and deaths that occurred in police personnel line of duty; and bulletins and excerpts from both the print and electronic media. These sources of information (i.e., primary and secondary sources) were subjected to interpretative philosophy and social construction paradigm. This was necessary because, there is generally inadequate or scanty information or research in the academic cycle on civilian violence against the police in the developing country context, stakeholder interactions, and constructivism (Bryman, 2012).

\subsection{Ethical consideration}

This research has both security and psychological implications for participants. The researchers and research assistants acknowledged and recognized the 
'fear' and consequences of participants divulging information on routine security operations and emotional trauma; having witnessed the many fatal injuries and deaths of colleague police officers in the line of duty. To safeguard participants from psychological trauma, respondents were preinformed of the nature and purpose of the study. Participants were also informed of non-material benefits in participating in the study. As a result, participants were given the freewill to either participate or withdraw from the study if they desire to do so. Accordingly, 11 participants opted out from the study during the data collection and information gathering processes. Research assistants were tasked or mandated to contact police officers via phone for the collection of completed questionnaires based on the agreed day and time given by respondents or police officers. Identity of participants (police officers) was anonymized to shield them from any form of victimization, exposure, demotion, transfer or any form of punishment owing to their participation in the study.

\section{Trends in killing of police officers}

This section presents a panoramic overview, evidence-based, and emerging trends in the upsurge and unrepentant killings of police officers in their line of duty by civilian assailants. The nature of these violent attacks on police personnel by a section of the civilian populace, leading to injuries and deaths and destruction of the police administration property, is categorized into a three-fold schema. These include the use of firearms and stabbings; vehicle knock downs/motor accidents; and mysterious police deaths in civilian populated communities. In recent times, civilian beatings of uniformed police officers has increased to an alarming proportion. Figure 1 below depicts the trends in police killings by civilians between 2007 2012 and 2013-2017

Figure 1:

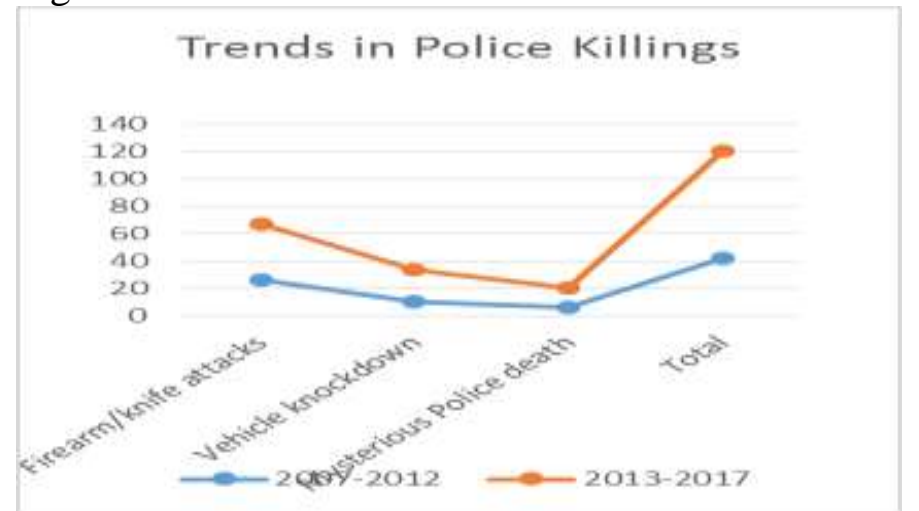

Source: Field Report and Police Statistics Unit, 2018
The statistics above indicate that more than $70 \%$ of killings of police officers by civilians result from the use of firearms and other dreadful or lethal weapons for the period 2007 to 2017. Small arms and light weapons are in circulation among unauthorized individuals including criminal elements in society. Attempts by the police administration to retrieve these unregistered firearms from the public, has so far proved daunting. Hence, it is not uncommon for civilian assailants to use firearms and other weapons such as machetes, daggers and knives to commit general crimes including violent attacks on police officers.

The second method regarding the use of violence against the police is vehicle knockdowns that result in police deaths. It is hard to believe that police officers who are accused of being 'murderers' and 'wicked' are rather at the receiving end of violent attacks from civilians. The statistics on civilians, ramming vehicles into police officers in their line of duty is alarming. This is depicted in Figure 1 above. Most police officers are usually knocked down by motorists at traffic intersections (where officers are stationed on a daily basis to observe or direct vehicular traffic) and at pedestrian crossings. Police officers in this category are reportedly beaten to pulp on a daily basis by commercial vehicle drivers and their conductors who are occasionally arrested for traffic-related offences. These incidences of civilian ferocious attacks on police officers make policing extremely difficult and its personnel vulnerable. There is a fast creeping fear and panic among police officers posted outside their barracks to perform official assignments. This phenomenon has created a somewhat de facto segregation between the police and the general Ghanaian public instead of working together to protect life and property.

The third method by which police officers lose their lives, is difficult to pin down to civilians or criminal gangs, that is, mysterious deaths of police officers in civilian populated areas. Due to infrastructural challenge, the police administration is unable to accommodate all police officers in barracks across the administrative regions and districts. Many of these police officers are found in rented premises in civilian populated areas. The mysterious deaths of police officers is 'celebrated' by some civilians as a fitting retribution of police action and inactions. This explains to some extent, why some policemen and women hardly wants to be identified as belonging to the police institution. They do not wear police uniform on their way to, or from 
work. They appear 'masked' - for fear of being identified and attacked.

\subsection{Why the strain relations between the police and civilian population?}

Policing in Ghana since the twilight of history has always been a matter of legitimation crisis. The discord and/or acrimony between the police service and their civilian counterparts, is far from apple-pie order. There is deep-rooted mistrust between the police service and the general public. This is exacerbated by the ongoing violent injuries and deaths involving both police officers and civilians in the operations of the former (i.e. police). Injuries and deaths of civilians caused by the police, are usually condemned by all facets of society, while a police officer, killed in the line of duty by civilian assailant ( $\mathrm{s}$ ) is given less attention and minimal condemnation. This is troubling, especially when the police are mandated by law to protect the very citizens who are now their assassins. This triggers the necessity to interrogate the main causes of the existing bad blood between the police service, and the wider public. For the purposes of this study, the causes of the strained-relations between the police service and the wider public, has been broadly categorized into four, thus, unprofessional use of firearms; legitimation crisis and/or public distrust; corruption; and negative media reportage.

First, the main cause of discord between the police administration and a section of the wider public in Ghana is rooted in the operations of the police itself. The 'sin' of the police service appears to stem from the ambiguous and lack of internationally acceptable or consensus definition of what constitute 'reasonable force'. This is widely acknowledged as one of the major causes of the stark strain relation between the police and civilians. While the public perceives police actions and inactions as unprofessional, that is, the use of chemical agents and live bullets in crowd management as 'excessive', especially when those actions lead to civilian injuries and deaths, the usual defence of the police service is that they are legally permitted to apply 'reasonable force' to save life and property when dealing with unruly behaviour of some civilians and other criminal elements in society. In the words of Geller and Scott (1992):

Any experienced police officer knows the potentially devastating effects of even justified shootings by the police - loss of life and bereavement, risks to an officer's career, the government liability to civil suits, strained police-community relations, rioting and all the economic and social crisis associated with major civil disturbances (Geller and Scott, 1992, p. 1). Strictly speaking, effective and efficient crowd control is still an area that the Ghana police service, lack ideas. As succinctly captured by Desmond et'al (2016): "Highprofile cases of police violence against unarmed citizens can undermine the legitimacy of legal authority" (Desmond, 2016 p. 857) Accordingly, whenever a police officer misapply or abuse the trust and confidence reposed in him/her by the public, the collective image of the police service, is completely damaged. Hence, the police service continue to suffer legitimation crisis and abuse from the public.

Closely connected to legitimation crisis is the erosion of public trust and confidence in the police service by a section of the public. It is common knowledge that the absence of public trust in the police, thus 'policing by consent' is difficult or impossible and public safety suffers (Goldsmith, 2005, p. 443). A key factor that erodes public trust in the police service, relate to accusations of the non-performance by the police service, its core function of protecting life and property. Many Ghanaians have persistently complained about the police failure, to either respond promptly to distress calls in emergencies, or the police providing conduits for suspected offenders to escape. This perception is heightened by several arrests of armed robbers, who turned out to be police personnel. It is not also uncommon for some unscrupulous police officers in Ghana to hire out their firearms and uniform to armed robbery gangs to perpetuate violence against the populace for their parochial interest. This fuels public resentment or bitterness against the police service; hence, compromises policecommunity relations for the maintenance of peace and security.

Thirdly, there is a plethora of research conducted by civil society organizations, including human rights advocacy groups, members in the academic fraternity and some 
media reportage, that portrays albeit unrepentantly, police corruption in Ghana (Boateng, 2012). The police service in Ghana has been systematically ranked as the most corrupt public institution in Ghana. Petty corruption, bribery, extortion, venality and the hushing up of some wrongdoings with the active connivance of some influential individuals against the less privileged members of society, are but a few of the corrupt, and corruption related allegations levelled against the Ghana Police Service. These perceptions adversely corrode public confidence or trust in the police service, compromise police efforts towards building a much stronger community relations; and undermine efforts aimed at building a healthy relationship with the public in order to ensure an effective maintenance of law and order. This phenomenon endangers stability and security in the realm of social, economic and political spheres. As succinctly captured by Pillay (2014):

The political cost of corruption can be ruinous. Vibrant democratic institutions depend upon the consent and support of the governed. Public confidence is necessary for democratic institutions to remain healthy and flourish. Corruption destroys the confidence of people $\ldots$ and undermine the very legitimacy of political institutions. In its most pervasive and entrenched forms, corruption can be a source of political instability ...corruption also has significant social cost - it creates a culture of poverty and crime and deprives the neediest elements of society from availing themselves the benefits of government resources (Pillay, 2014, p. 1).

In spite of the fact that the police administration has in recent times worked and is still working to cleanse the police service of deviant staff through dismissals and prosecution, public perception of the institution as the most 'corrupt' continue to be an albatross on the neck of the police administration. Several attempts aimed at reforming and rebranding the police institution as a way of winning the trust and confidence of the public, have on many occasions, been dogged or marred by fresh revelations of police corruption, extortion, misconduct, torture and unfortunate deaths of civilians in police operations. This has been a major challenge for the police administration. Finally, there appears not to be a cordial relationship between the police service and the media landscape in Ghana. Cases of journalists being manhandled, or in some instances brutalized by the police, are a frequent occurrence. For instance, a newspaper publication in March 2019 suggest that, there has been more than twenty-five (25) policemilitary brutalities on journalists since 2006 . The paper regrets that no prosecution of culpable police officers took place in the same period (Daily Graphic, 2019). According to Goldsmith (2005):

Media attention has the ability to convert a single instance in a confined setting, into a matter of mass notoriety, an 'experience' of police available to the habituses of millions (Goldsmith, 2005, p. 459).

The extensive or prolonged negative media reportage, coupled with social media posts, depicting police use of excessive force, reinforces unabatedly, the perception that the police are murderers in uniform; wicked; extortionist; incompetent; discriminatory; unprofessional; lacks sympathy; wrong profiling of people and communities; and a complete show of indifference to the citizens' plight. In this perspective, the police service is pigeonholed or stereotyped as an institution that exist to serve itself. The police service equally accuses the media of exaggeration and manipulation of facts to give it a bad name. These recriminatory arguments between the police and the media is unnecessary to say the least. It gives opportunity to criminal elements in society to cash in to continue to perpetuate all manner of crimes; while the distrust between the police service and law abiding citizens or civil society continue to surge. It is however important to note that, some of the high profile harangue on the police by the media (e.g. tagging the police as murderers, brutish, corrupt, etc.) and the general public condemnation accompanying such reportage, only turns out - at least in most cases - to be damp squibs and lack merit. However, in the court of political opinion, the police service, is 'convicted' and 'imprisoned' without a hearing or trial.

\section{Results and Discussion}

The goal for embarking on this study was to explore variations overtime in the killings of police officers in their line of duty by civilian assailants. The study was also to sample/solicit the views of police officers on the causes of the strain relations that 
exist between the police service and the general Ghanaian public. The results below are based solely on the varied responses of participants of the study. These responses are analyzed based on two main thematic areas:

\subsection{Variations in killing of police officers}

Participants exhibited clear understanding of contemporary risks in policing, based on the field report. The participants contend that, their job schedules have become inextricably linked to violent deaths, incapacitation and injuries. While the police service is on the heels of miscreants in society who use firearms on them at will, ordinary citizens also target them (e.g., violent attacks on police officers in their line of duty), with its associated tension and consequences. One police officer states:

Police deaths and injuries recorded over the past three or so years is frightening. Many of us no longer put on police uniforms on our way to work or returning home from work. Once you are in uniform, you risk being shot at, killed or attacked for unknown reason or reasons. We are the targets for armed robbers and members of society in general. The death of a police officer is seen as 'normal' or 'celebrated' by some civilians. As a result, police officers are cautious and will take any appropriate action necessary to defend ourselves. Now, who protects the protector (police)?

Captured below is an aggregate of the views expressed by the multitude of respondents on variation of violent police deaths and injuries overtime:

The number of violent police deaths and injuries recorded by the Police Statistics Unit can't be correct. Violent police deaths perpetuated by civilians against the police is more than the official figure. We strongly believe our colleagues who sustain fatal injuries or died in the process, were not duly recorded. We hear of police deaths and injuries across the capital city on a daily basis. Police deaths, especially those guarding banks and other financial institutions are killed in broad daylight during robbery operations. Compensation that is often paid to the slain officers' families by the police administration, can at best be described as insult.
The participants provided contact phone numbers of families of nine police officers whose service numbers and names were not captured or included in the official data or statistics of slain officers by the police administration. Spouses of these slayed officers were contacted by the research team to confirm the veracity or otherwise of the information gathered. The spouses corroborated the assertion of the respondents. Many of these officers died weeks after sustaining various degrees of fatal injuries in the line of duty. According to four of the bereaved families contacted, the injuries were sustained during shoot-outs with armed robbers. The others died from injuries sustained through unwarranted civilian attacks on them, either through firearms or the use of offensive and deadly weapons such as knives and machetes. According to the police officers, lack of job openings in other sectors of the Ghanaian economy is what keeps them in the police service. They are willing to resign as police officers if other job opportunities are available to them. A small number of police officers, have however resigned.

Based on the interaction with respondents on the variations of killing of police officers overtime, the key finding of this study reveals that police officers are apprehensive about their job (e.g. policing is directly linked with death and injuries); and the seemingly lack of, or inadequate support from the general public. Hence, police personnel who participated in the study are more likely to resign from the police service if offered another job opportunity. The study also found that, morale of personnel is fast waning at an exponential rate. Out of panic and fear of death from attacks, some police officers on duty or on operations are more likely to open fire on the public, the moment they sense danger. Self-defense is usually used as an alibi for police actions involving the general public.

\subsection{Key issues of police-civilian imbroglio}

Participants showed an understanding of some of the key issues of police-civilian antagonistic relations. The muddiness of police-civilian imbroglio is borne out of the perception of the former (police) as an institution that perpetuate violence and hatred against civilians. According to the respondents, a section of the public perceive the police service as an institution that exist to serve itself and not the public. Respondents of the study expressed the following thoughts of police-civilian relations: 
That the police are wicked, murderers, torturers, illegally amassing of wealth through bribery and extortion, contorting and distortion of facts in the law courts to favour affluent members of society against the poor, and a lackadaisical response or attitude to distress calls from the public. The mere sighting of a police officer invoke images of brutality, bribery and extortion among some citizens.

Respondents were of the view that the above perceptions of the police service by the wider public explains to some extent, the antagonistic relationship that exist between the police and the general Ghanaian public. These perceptions are aggravated by the constant media hype, albeit, negatively depicting police operations. Hence, recurrent attacks on the police on a daily basis is considered a matchup to police 'brutalities and violence' against the populace. According to the respondents:

We fear law abiding civilians than armed robbers, drug barons and other miscreants in society. For the misfits in society, police officers are willing and capable of dealing with them appropriately. We always prepare when we are to embark on operations against criminals in their hideouts. When we are injured or killed in the process, we understand that it is part of our occupational hazards or risks. But the unsuspecting ordinary civilians we least suspected, are those who constantly unleash unwarranted violent attacks on us; some police officers are killed or injured in the process. Whenever we try to defend ourselves by applying 'reasonable force', the whole society descend on us for using excessive force. But we can confidently say that we are not bad as society portray us. The police administration is a human institution; and therefore not perfect. Some police officers may engage in acts that are unprofessional. But it does not make all police officers or cops bad.

Responses of participants reveal the dilemma of police officers in the performance of their core functions. They are clearly aware of the dangers associated with policing. They are alienated because, they are the targets for attacks by the civilian population, which they are mandated to protect by law. The police service is therefore caught up in a web. First, they are targeted by criminal gangs who frequently engage them in shootouts. Second, the police service is negatively portrayed, abused by the media and manipulated by politicians to engage in acts that are inconsistent with their professional duties. Accordingly, the police administration is accused of being in 'bed' with incumbent governments and their surrogates. Victimization of police officers feature prominently, whenever there is a change of government. Consequently, police personnel are not only gripped with fear of the unknown in the discharge of their responsibilities, but timidity has taken a greater part of the outlook of police morale. The current trend in the killing of police officers by both civilians and criminal elements in society further demoralizes the ability of the police to perform their core functions creditably.

\subsection{Bridging police-community relations: A hard pathway to public trust?}

Effectiveness and efficiency of modern policing is contingent on public trust and cooperation with the police in all facets relating to security. Involving community members in modern policing is an efficient mechanism in combating crime. In most instances, members of the community are used by the police as their 'eyes' and 'ears' to gather valuable intelligence necessary to deal with all forms of potential security threats. The success of any police operation is largely dependent on the cooperation of other institutions or agencies within a community. As noted by Kratcoski (2010):

It has long been recognized by police administrators that police work is dependent on other agencies and organizations, both public and private, within the community (Kratcoski, 2010, p. 14)

The police administration in collaboration or working together with community members will not only enhance security in the community they operate, but it has the potential to maximize public trust in the activities of the police. This collaboration will be effective if the police hierarchy decentralizes some of its 'powers or functions' to community members in the areas of crime reporting and analysis, education, night patrols or community watchdog committees, citizen's arrest of alleged offenders, all in an effort to ensure effective policing.

Capacity building of police officers, including what Burke (1998), refers to as 'zero tolerance policing' (generic term for a policing style that is 
proactive, confident and assertive) are key to restoring and exudate great public confidence in the police. Public confidence in the police will come about if professionalism on the part of the police service is enhanced. The use of firearms, tear gas, water cannons, etc., could be used sparingly and only when necessary - this therefore calls for education of serving and would-be police officers to achieve the desired results. The usual hurried deployment and use of firearms at the least provocation by the police has led to unintended civilian causalities, including deaths. This must be checked through retraining of police personnel in weapon handling and gradual demilitarization of the service. It is altruistic that the use of firearms by the police service is inevitable, so long as criminals and other miscreants in society continue to operate. However, in almost all police operations, personnel must aim to reduce 'innocent' and unarmed civilian fatalities. In order to build public trust and confidence in the police, the top hierarchy of the police administration ought to hold accountable, recalcitrant officers who systematically and unrepentantly misconduct themselves against established norms, rules and regulations of the service. This will send a strong signal to the general public that the police administration does not and will not condone wrongdoing in its fold in the discharge of their constitutional duties.

An effective and efficient discharge of police duties, most often boosts the image of the police service. The speed at which the police service respond to emergency calls, is a key factor in building trust and confidence in the police by the public at large. Modern policing requires that, there must be processes deliberately designed to timely serve the needs of the public regardless of the period or time of day. If the citizens feel secured as a result of the effectiveness of the police service, there will ultimately be a cordial relationship and collaboration between the police and the public to mutually combat crime in society.

The police ought to be seen working towards reforms. Admittedly, the police administration has undertaken several reforms in the past, all aimed at making the police service more professional and relevant in its operations - both within and without. Yet, reforms recidivism has been the bane of the police administration. The police administration should aim at not allowing rescission to take the center stage in the reforms, but collaborate continuously with all relevant agencies, organizations, academics, government and the general public to extricate the police service from the widely held notion of the public that the police service is embroiled in wanton corruption, bribery, extortion, discrimination, manipulation of evidence against less privileged in society, wicked, and 'witch-hunting', instead of educating the general public on collaborative policing. These accusations, whether real or imaginary, the police administration has a daunting task to change the status quo i.e., attitudes of police personnel on one hand, and the perceptions of the general public on the other, in order to court the trust of the public.

\section{Conclusion}

Policing is a difficult and a risk-laden job. The core mandate of the police, thus detecting, preventing and combating crime, maintenance of law and order, are vital for the peaceful and harmonious continuous survival of humanity. The police service is also mandated to use 'reasonable force' wherever necessary to maintain law and order. In this case, what is the definition of reasonable force' and who defines it? These nagging questions makes the enforcement of law and order by the police, a tricky one. For, when citizens turn violent with its consequence of disturbing public peace, the police have a duty to enforce, restore and keep the peace. This study does not hold breath for police officers who deliberately misconduct themselves against the public. But it is to shed light in the context in which the police operate, vis-à-vis the enforcement and performance of their core mandate or functions. This calls for a concerted effort by all stakeholders, including the media in particular, to assist the police. A well-functioning police service would ultimately inure to the benefit of the law abiding in society.

Policing all over the world, suffice is to say that, is an essential service to citizens that can make or break a State. The police service, is arguably one institution that is visible and interacts more frequently with the public than any other State security set-up. It is therefore imperative for all relevant stakeholders in society, such as political leaders, academics, opinion leaders in various communities, traditional leaders, etc., to collaborate with the police administration to educate the wider public against violent attacks on police officers; while the police hierarchy work (e.g. train officers) to improve upon police professionalism and responsible use of firearms. The rationale is to build peace and trust between citizens and the police service in Ghana.

This paper proposes a paradigm shift or model on security as a quid pro quo to reducing the recurrent incidences of violence against the police. 
The first step in fostering police-civilian relations is demilitarization of the police service. The firing of live bullets on civilians in almost all police operations is anachronistic in modern policing; and it further dichotomizes police from the public.

The police as a matter of urgency, need to collaborate with traditional and opinion leaders to organize series of imbizos with the overall goal of achieving a healthy co-existence and harmonious relationship between the police and the general public - this is necessary, especially in communities where violence against the police is pervasive. Another way the police service can build public trust is to collaborate with community members to prevent crime. This will assist the police to be less reactionary in crime prevention. Policing, it is said, is a shared responsibility involving all relevant stakeholders or actors in society.

The seemingly 'institutionalization' of epidemic violent attacks/assaults by a section of the public on police officers, destruction of police property, etc., ought to stop, as a pre-condition to restoring sanity between the police and the public. Any deliberate attack on the police service is tantamount to an attack on the State. These attacks and invectives against the police service are inflammatory, provocative, pejorative, and demoralizing. The core mandate of the police (i.e., to protect life and property) is jus cogens - principles or norms of international law that cannot be set aside - and these are likely to be compromised, unless there is a concerted effort by the government of the day and civil society, to protect and confer dignity upon the police to deliver. In this perspective, the most important conundrum is to redirect and build the capacity of the police service in line with global standards of policing. The police and citizens must work synergistically together as a sine quo non to deal effectively with miscreants in society. The current strain relation between the police and a section of the public, is not only egregious, but it hampers the well-functioning of the former. The only beneficiaries probably to this 'stand-off' between the police and the public, are criminals who rob and sometimes kill civilians while the police, for decades, endure violent deaths and attacks from both criminal elements and other so-called law abiding citizens.

\section{Acknowledgement}

The authors wish to thank the Police Administration for their friendship and providing data of demised and injured police officers in the line of duty. We also extend our gratitude to
Professor Kwame Boafo-Arthur and Dr. Mohammed Issah for their invaluable suggestions and direction.

\section{Funding Information}

The authors received no funding in lieu of this manuscript. Hence, no competing interest.

\section{Author Contributions}

Awaisu I. Braimah: Developed instrument for data collection, conducted data analysis and contributed to writing the article.

Alhassan S. Bawah: Contributed to the development of the instrument for data collection, writing of manuscript and edited the manuscript.

\section{Ethics}

This manuscript is original and has not been submitted or published elsewhere. Both authors have read and approved the manuscript for publication. No ethical issues are involved.

\section{References}

[1] Bernasconi, R. (2014). When police violence is more than violent policing. The New Centennial Review. Vol. 14, No. 2, pp 145-152. Retrieved from:

http://www.jstor.org/stable/10.14321/crnew.cent revi. 14. 2.0145

[2] Boateng, F. D. (2012). Public trust in the police: Identifying factors that shape trust in the Ghanaian police. Working paper No. 42 of International Police Executive Symposium, Geneva Center for the Democratic Control of Armed Forces, and Coginta - For Police Reforms and Community Safety

[3] Braimah, A. I., Ewusie, J. T. \& Mensah, M. A. (2017). Mega-Lecture theatres, disability education and human rights: A comparative study of four selected Ghanaian public universities. International Journal of Research Studies in Education Vol. 7, No. 4, pp 27-40

[4] Bryman, A. (2012). Social research methods $\left(4^{\text {th }}\right.$ edition). New York, NY: Oxford University Press

[5] Daily Graphic, (2019) Tuesday, March 19, 2019. Issued No. 20938, pp. 1 \& 16.

[6] Desmond, M, Andrew, V. P. \& David, S. K. (2016). Police violence and citizen crime reporting in the black community. American Sociological Review. Vol. 81(5), pp 857 - 876. DOI: $10 / 1177 / 0003122416663494$. SAGE 
[7] Geller, W. \& Scott, M. S. (1992). Deadly force: What we know. Washington DC: Police Executive Forum

[8] Ghana Police Service (2010). Police handbook. Accra, Ghana, pp 26

[9] Goldsmith, A, (2005). Police reform and the problem of trust. Theoretical Criminology. Vol. $9(4) ; 443$ - 470; 1362 - 4806. DOI: $10.1177 / 1362480605057727$

[10]Hopkins, B. R. ed. (1998). Zero tolerance policing. Leicester: Perpetuity Press.

[11]Kratcoski, P. (2010). Police without borders: An overview. In C. Robertson, D. Das \& J. Singer, Police without borders: The fading distinction between local and global. Boca Raton, FL: CRC Press, pp. 1 - 26

[12]Margarita, M. (1980). Police as victims of violence. The Justice System Journal. Vol. 5. No. 3. I Innovation in Criminal Justice. pp. 218-233. Retrieved from http://www.jstor.org/stable/20877597.

[13]McEwen, T. (1996). National data collection on police use of force. Bureau of Justice Statistics: U.S. Department of Justice and National Institute of Justice

[14]Pillay, S. (2014). Development corruption in South Africa: Governance matters, USA, Palgrave Macmillan: St. Martin's Press LLC. 